\title{
A new species of the genus Potamalpheops (Crustacea: Decapoda: Alpheidae) from the intertidal mangrove swamps of South Vietnam
}

\section{Новый вид рода Potamalpheops (Crustacea: Decapoda: Alpheidae) из приливно-отливных мангровых болот Южного Вьетнама}

\author{
Ivan N. Marin \\ Иван Н. Марин
}

\begin{abstract}
A.N. Severtsov Institute of Ecology and Evolution of RAS, Moscow 119071, Russia. E-mail: coralliodecapoda@mail.ru Joint Russian-Vietnamese Tropical Research and Technological Center, Hanoi, Vietnam.

Институт экологии и эволюции им. А.Н. Северцова РАН, Москва 119071, Россия.

Совместный Российско-Вьетнамский тропический научно-технологический центр, Ханой, Вьетнам.
\end{abstract}

KEY WORDS: Biodiversity, intertidal mangrove swamps, burrows, South Vietnam, Indo-West Pacific.

КЛЮЧЕВЫЕ СЛОВА: Биоразнообразие, приливно-отливные мангровые болота, норы, Южный Вьетнам, Индо-Вест Пацифика.

ABSTRACT. A new, possibly, infaunal species of the genus Potamalpheops Powell, 1979 (Crustacea: Decapoda: Alpheidae), Potamalpheops kisi sp.n., is described from the intertidal mangrove swamps of the Can Gio Mangrove Biosphere Reserve, South Vietnam. The new species clearly belongs the "P. monodi" species group, but can be easily separated from related species ( $P$. pininsulae Bruce et Illife, 1992, P. tigger Yeo et P.K.L. Ng, 1997 and P. johnsoni Anker, 2003) by the length and shape of rostrum, the length and proportions of carpus and palm of pereiopods I and II, as well as some other minor morphological features. All individuals of the new species were pumped out of burrows in anoxic swamp mud, while no individuals were collected using a hand net during extensive sampling in the same habitats, suggesting that the new species inhabits in a burrow system. No evidence of relationship to any host species is available, since individuals of the new species were collected from different burrows and never with syntopic larger burrowing animals. Observations in situ at nighttime revealed that individuals of Potamalpheops kisi sp.n. freely move inside burrows located above the water level, similar to other mangrove semi-terrestrial shrimp Merguia oligodon, which possibly allows surviving in anoxic conditions of swamp soils; such behavior is described for the genus Potamalpheops for the first time.

How to cite this paper: Marin I.N. 2021. A new species of the genus Potamalpheops (Crustacea: Decapoda: Alpheidae) from the intertidal mangrove swamps of South Vietnam // Arthropoda Selecta. Vol.30. No.2. P.179-191. doi: 10.15298/arthsel.30.2.05

РЕЗЮМЕ. ОПисан новый, возможно, симбиотический вид рода Potamalpheops, Potamalpheops kisi sp.n., из приливно-отливных мангровых болот биосферного заповедника Канзе в Южном Вьетнаме. Он принадлежит видовой группе "P. monodi", внут- ри которой хорошо отделяется от родственных видов (P. pininsulae Bruce et Illife, 1992, P. tigger Yeo et P. K.L. Ng, 1997 и Potamalpheops johnsoni Anker, $2003)$ длиной и формой рострума, карпуса и проподуса переопод I и II, а также некоторыми другими морфологическими признаками. Все особи нового вида были собраны с помощью насоса из нор в аноксичной болотной грязи, ни разу не попавшись на поверхности в ручной сачок. Это вероятно, говорит о том, что он обитает исключительно в системе нор. Никаких доказательств взаимоотношений с другими видами-хозяевами на данный момент не имеется, так как особи нового вида были собраны из разных нор и никогда не попались совместно с синтопическими более крупными норными животными. Наблюдения in situ в ночное время показали, что Potamalpheops kisi sp.n. может свободно перемещаться внутри нор, расположенных выше уровня воды, подобно другим мангровым полу-наземным креветкам Merguia oligodon. Возможно, это позволяет выживать в аноксичных условиях болотных почв. Такое поведение описано для рода Potamalpheops впервые.

\section{Introduction}

Mangrove forests play an important ecological role in tropical coastal areas around the world, providing a wide biological diversity and range of ecological and social services, such as protection from storms and erosion in coastal areas [Moberg, Rönnbäck, 2003; Walters et al., 2008]. Mangroves are also one of largest irrecoverable carbon stores [Goldstein et al., 2020]. Nevertheless, ecological structure of mangrove communities and their diversity has not yet been completely studied. Moreover, mangroves are greatly threatened, about $20 \%$ of the total mangrove area has been lost since 1980 [FAO, 2007], while at least $35 \%$ of the 

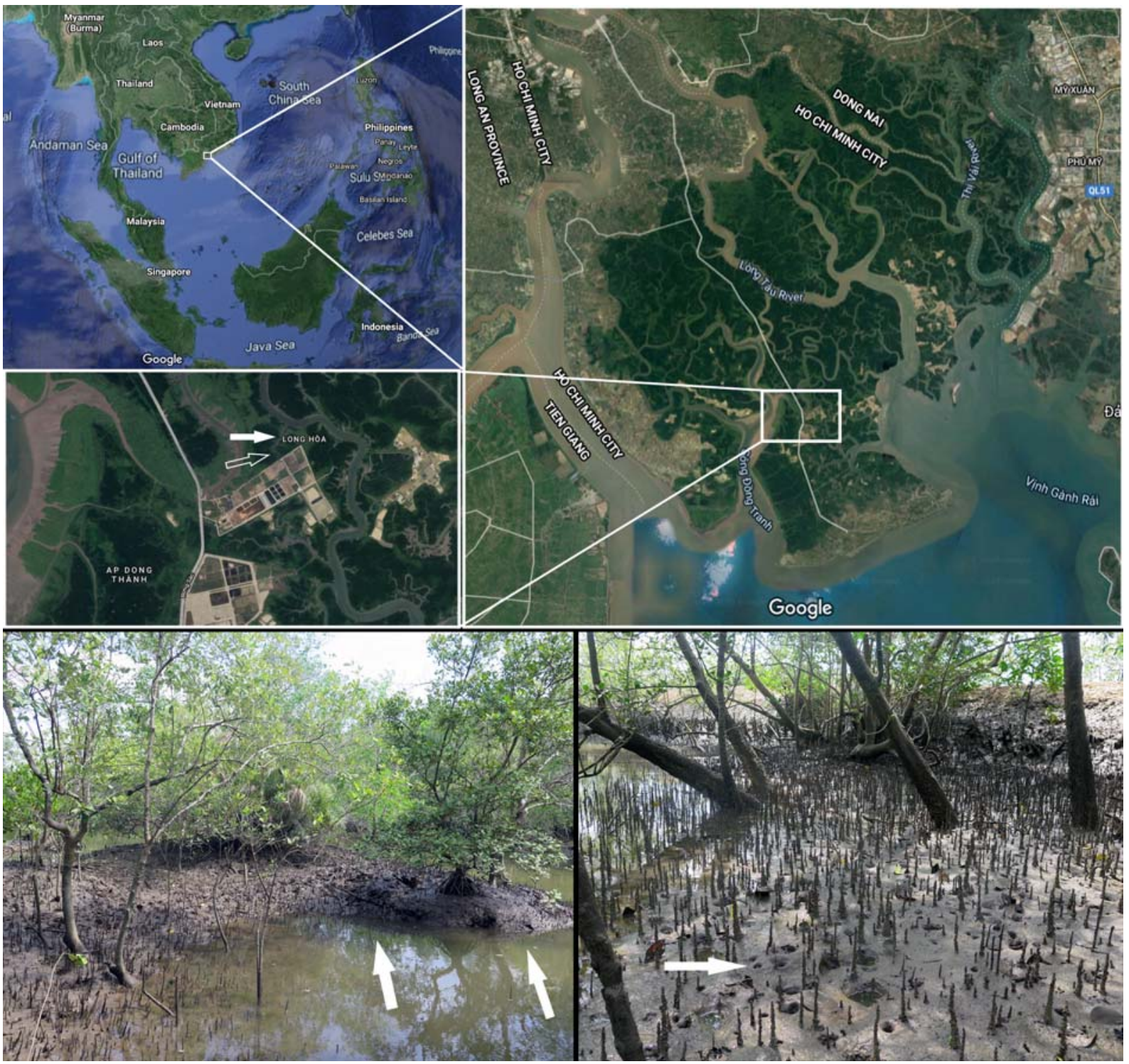

Fig. 1. The locality of the Can Gio Mangrove Biosphere Reserve, South Vietnam (upper map), and typical biotopes in the locality, where Potamalpheops kisi sp.n. was collected (lower). White arrows indicate the location of burrows, where shrimps were collected using yabby-pump.

Рис. 1. Расположение мангрового биосферного заповедника Канзе в Южном Вьетнаме (верхняя карта) и типичные биотопы в местности, где был собран новый вид Potamalpheops kisi sp.n. (нижняя карта). Белые стрелки указывают на расположение нор, где креветки собирались с помощью ручного насоса.

area was lost between 1980 and 2000 worldwide [Valiela et al., 2001].

The Can Gio Mangrove Biosphere Reserve $\left(10^{\circ} 22^{\prime}\right.$ $\left.-10^{\circ} 40^{\prime} \mathrm{N}, 106^{\circ} 46^{\prime}-107^{\circ} 00^{\prime} \mathrm{E}\right)$, represented mostly by about 20-year-old monoculture forests of Rhizophora apiculata Bl. (Rosanae: Rhizophoraceae), spans approximately 75000 ha about $65 \mathrm{~km}$ south from Ho Chi Minh City in South Vietnam. During the Second Indochina War, more than $90 \%$ of the natural mangroves in Can Gio were destroyed [Tran et al., 2004]. In 1978, replanting began, mostly with $R$. apiculata, for the production of charcoal, poles and firewood [FAO, 1993]. In 2000, the area was declared an UNESCO
Biosphere Reserve. At present, part of the territory of this park is still used as agricultural, in particular for shrimp farming. The diversity of decapod crustaceans in this area is very high and quite unique, new species from Can Gio Reserve and adjacent area are described regularly [Van Xuan, 1992, 2001; Chertoprud et al., 2012; Diele et al., 2013; Ashelby et al., 2018; Shih et al., 2019].

The burrowing infaunal diversity is rather depleted in upper mangrove zones, and most of species living there are specific and highly adapted for mangrove swamps and specific ecological conditions [Ng, Sivasothi, 2002; Walters et al., 2008; Hossain, Nuruddin, 
2016]. A detailed study of biodiversity of mangrove swamps in the Can Gio Mangrove Biosphere Reserve in April 2020 revealed the presence of an undescribed, probably, infaunal species of the genus Potamalpheops Powell, 1979 (Crustacea: Decapoda: Caridea: Alpheidae) found inside burrows of different invertebrates.

\section{Material and Methods}

Sampling was carried out within the scientific program of the Joint Russian-Vietnamese Tropical Research and Technological Center (Tropical Center) in the upper zone of deep mangrove forests, mostly represented by monoculture forests of Rhizophora apiculata Bl. (Rhizophoraceae), in the Can Gio Mangrove Biosphere Reserve near the Vietnam-Russian Climatic Research Station (CRS “Can Gio") $\left(10^{\circ} 27^{\prime} 19.1^{\prime \prime} \mathrm{N}\right.$ $106^{\circ} 53^{\prime} 32.9^{\prime \prime} \mathrm{E}$ ) (see Fig. 1) in March-April (dry season) 2020. Animals were collected from different burrows in muddy bottom using a bait suction pump (yabby-pump). All collected animals were relaxed in a clove oil and then photographed alive using a Canon G16 digital camera; and then preserved in 90\% ethanol solution. The drawings were made using lucida camera attached to Olympus SZX10 stereomicroscope.

Carapace length (pcl., in $\mathrm{mm}$ ), measured from the tip of the rostrum to the midpoint of the posterodorsal margin of the carapace, and total body length (tbl., in $\mathrm{mm})$, measured from the tip of rostrum to the distal margin of the telson, are used as standard measurements. The type material is deposited in the collection of the Zoological Museum of Moscow State University, Moscow, Russia (ZMMU) and the personal author's collection in the A.N. Severtsov Institute of Ecology and Evolution of Russian Academy of Sciences, Moscow, Russia (LEMMI).

Cytochrome c oxidase subunit I (COI) mtDNA, used as one of the most informative gene markers for genetic studies at population and species level [Avise, 1993], was amplified with the help of the universal primers LCO1490 (5'-GGTCAACAAATCATAAAGATATTGG-3'), HC02198 (5'-TAAACTTCAGGGTGACCAAAAAATCA-3') [Folmer et al., 1994], and COIF (5'-CCAGCTGGAGGAGGAGAYCC-3'), H7188 (5'-CATTTAGGCCTAAGAAGTGTTG-3') [Kessing et al., 1989; Knowlton et al., 1993]. PCR products were performed on amplificator T100 (BioRad, USA) under the following conditions: initial denaturation at $96{ }^{\circ} \mathrm{C}$ for $1.5 \mathrm{~min}$ followed by 42 cycles of $95^{\circ} \mathrm{C}$ for $2 \mathrm{~min}, 49^{\circ} \mathrm{C}$ for 35 seconds, and $72^{\circ} \mathrm{C}$ for $1.5 \mathrm{~min}$, followed by chain extension at $72^{\circ} \mathrm{C}$ for 7 $\mathrm{min}$. The volume of $10 \mathrm{uL}$ of reaction mixture contained $1 \mathrm{uL}$ of total DNA, $2 \mathrm{uL}$ of $5 \mathrm{xPCR}$ mix (Dialat, Russia) and $1 \mathrm{uL}$ of each primer. The amplification products were separated by using gel electrophoresis of nucleic acids on a $1.5 \%$ agarose gel in 1xTBE, and then stained and visualized with $0.003 \%$ EtBr using imaging UV software. DNA nucleotide sequences were determined using Genetic Analyzer ABI 3500 (Ap- plied Biosystems, USA) and BigDye 3.1 (Applied Biosystems, USA) with direct and reverse primers. Aligned sequences of COI mtDNA gene marker, 658 base pairs in length, are deposited in GenBank (NCBI). Unfortunately, the obtained molecular genetic data are the only ones for the genus Potamalpheops, so no further phylogenetic analysis was performed.

\section{Taxonomy}

Order Decapoda Latreille, 1802

Family Alpheidae Rafinesque, 1815

Potamalpheops Powell, 1979

\section{Potamalpheops kisi sp.n. Figs 2-6.}

HOLOTYPE, + , tl. $12.3 \mathrm{~mm}$, cl. $3.0 \mathrm{~mm}$, ZMMU Ma-6118, VIETNAM, Ho Chi Minh District, Can Gio Mangrove Biosphere Reserve, $10^{\circ} 27^{\prime} 19.1^{\prime \prime} \mathrm{N} 106^{\circ} 53^{\prime} 32.9^{\prime \prime} \mathrm{E}$, inside burrows along the banks of canals deep in mangroves, coll. I. Marin \& S. Sinelnikov, 25 April 2020.

ALLOTYPE. $\sigma^{7}$, tl. 11.8 mm, cl. 2.7 mm, ZMMU Ma-6119, same locality and date as for holotype.

PARATYPES, $1 \sigma^{7}, 1$ ( 1 (ZMMU Ma-6120), $11 \sigma^{7} \sigma^{7}, 6$ 우, LEMMI - same locality as for holotype, 17April - 2 May 2020.

DESCRIPTION. Small-sized alpheid shrimp with subcylindrical body (Figs 2, 6).

Carapace (Fig. 2) smooth, glabrous, with well-developed cardiac notch; anterior margin with feebly developed cornea of eyes exposed dorsally for $80 \%$ (Fig. $3 a-d, f-i$ ); extracorneal tooth well developed, acute, inferior orbital angle feebly produced blunt; pterygostomial angle slightly produced, rounded; ventral margin of branchiostegite smooth; rostrum smooth, relatively medium, acute, compressed, without dorsal carina, about 3.5-4 times longer than basal width, reaching or slightly overreaching distal margin of basal segment of antennular peduncle.

Pleon (Fig. 2) smooth, glabrous, pleura of first 3 somites broadly rounded, ventrally unarmed and mostly smooth, pleura of somites 5 and 6 with acute posterolateral angle, posteroventral angle of segment 6 with larger triangular articulated plate (Fig. $6 b$ ).

Telson (Fig. $6 a$ ) about 2.5 times longer than proximal width, slightly tapering distally, with 2 pairs of small dorsal spines located at about 0.4 and 0.65 of telson length, each spine about 0.1 of telson length; posterior margin (Fig. 6c) about half of anterior margin width, with central third strongly convex, armed with 12-14 long plumose marginal setae, with 2 pairs of long and robust posterior spines, lateral spines about twice smaller than medial; anal tubercles distinct.

Antennular peduncle (Fig. $5 a$ ) robust; proximal segment about twice longer than distal width, distal margin finely denticulate dorsolaterally, with large distally acute ventromedial lamella; statocyst well developed; stylocerite short, acute, extending beyond midlength of intermediate segment; intermediate segment subcylindrical, about 1.4 times as long as wide, subequal in length to basal segment and slightly longer than distal segment; distal segment subcylindrical, about 1.2 times as long as wide. Upper flagellum (Fig. 5b) biramous, with proximal 10-11 articles fused, bearing aesthetascs, equal to about half of the length of carapace; shorter free ramus with 4 small articles, longer free ramus slender; lower flagellum slender, about 1.5-2 times longer than carapace. 


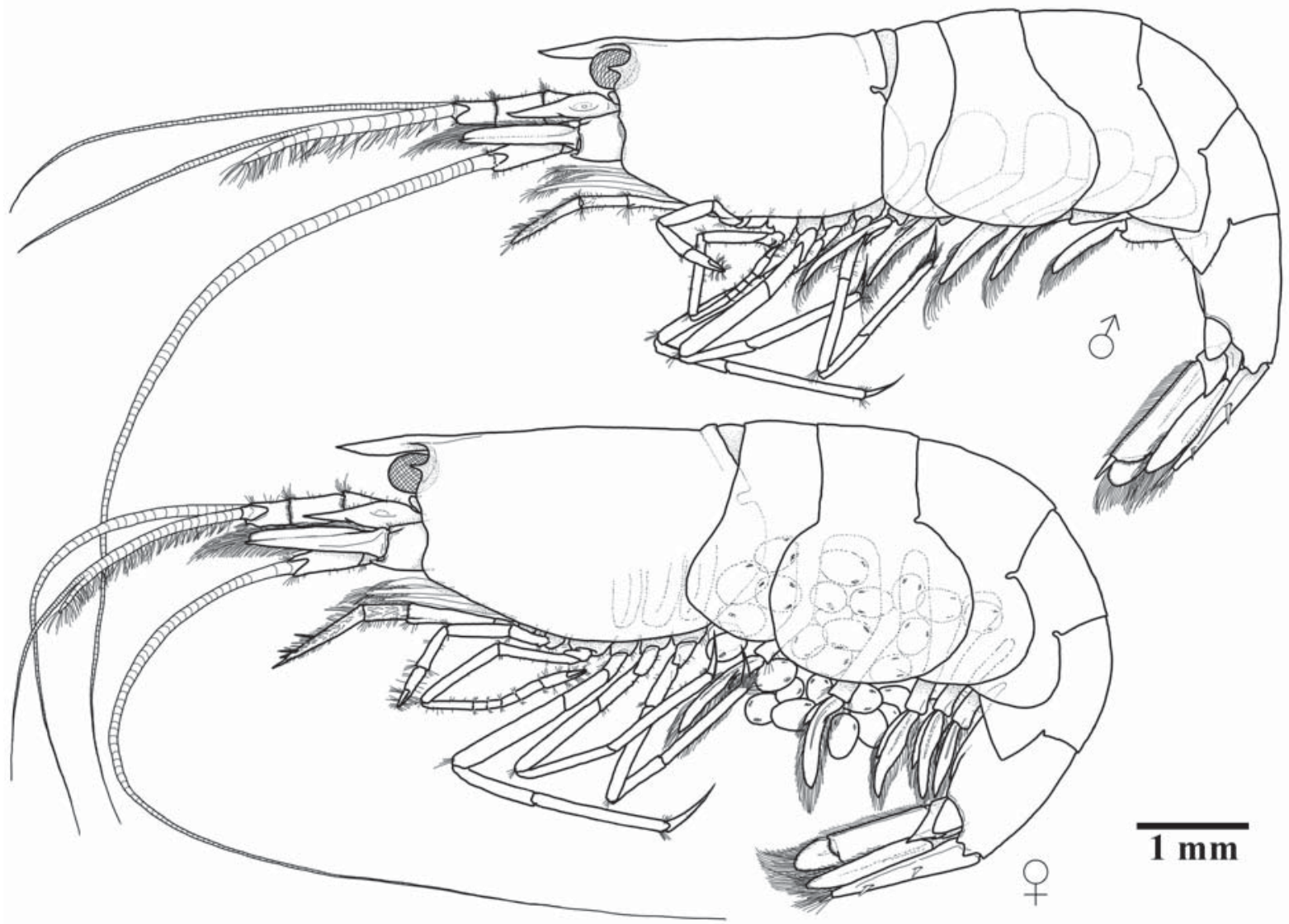

Fig. 2. General view of Potamalpheops kisi sp.n. (LEMMI), habitus in lateral view.

Рис. 2. Общий вид Potamalpheops kisi sp.n. (LEMMI), вид сбоку.

Antennal basicerite (Fig. 5c) robust, armed with strong distolateral tooth; carpocerite short, stout, about 3 times longer than wide, reaching to about 0.8 of scaphocerite length; flagellum well developed, about 2.5 longer than the length of carapace; scaphocerite well developed, reaching to distal margin of antennular peduncle, about 1.8 times longer than maximal width, broadly rounded distally, with small acute distolateral tooth slightly exceeding distal margin of lamella.

Eye (Fig. 3e) with well-pigmented hemispherical cornea, exposed dorsally for about $80 \%$, with unarmed anteromedial margin of eyestalk.

Epistomal region normal, labrum not protuberant. Mandible (Fig. 4a) with robust corpus; palp 2-segmented, with suboval and compressed distal segment, about 1.4 times as long as wide, with plumose marginal setae, proximal segment subcylindrical and smooth; molar process subcylindrical, obliquely truncate distally, exterior surface densely covered with tooth-like spines; incisor process with 5 acute distal teeth. Maxillula (Fig. 4b) with bilobed palp, distal lobe slightly larger than proximal, with long slender simple seta, proximal lobe smaller than distal, with spiniform sparsely setulose seta; upper lacinia with 2 rows of simple spines on distal margin and with 3 plumose setae dorsally; lower lacinia slender than upper lacinia, tapering distally, covered with numerous simple and plumose setae. Maxilla (Fig. 4c) with slender smooth palp, basal endite broad, with feeble division into lobes, with numerous stout simple setae medially, coxal endite feebly developed, sparsely setose; scaphognathite normal, about 4 times as long as broad. Maxilliped I (Fig. 4d) with slender unsegmented palp, reaching to anterior margin of caridean lobe, with 2 large plumose setae distomedially and a row of shorter plumose setae medially; basal endite simple, sparsely setose; exopod well developed with numerous plumose setae distally, caridean lobe small, narrow, with a row of plumose setae medially; epipod large, simple. Maxilliped II (Fig. 4e) with normal endopod, dactylar segment narrow, about 2.5 times as long as wide, with numerous serrulate spines medially; propodal segment bluntly produced distally, with numerous finely plumose spines and spiniform setae distally; basis excavate distomedially; exopod well developed with numerous plumose setae distally; epipod well developed, suboval, widening distally, without podobranch. Maxilliped III (Fig. 4f) with moderately robust endopod slightly exceeding antennal carpocerite; ischiomerus about 6 times as long as wide, with subparallel margins, with small simple setae medially and distally; penultimate segment 3.5 times longer than broad, subcylindrical; ultimate segment about 6 times as long as proximal width, tapering distally, with 3 short stout spiniform setae distally, mesial face with transverse rows of serrulate setae, lateral face sparsely setose; exopod reaching distal margin of penultimate segment, with numerous plumose setae distally; coxa broadly produced medially, sparsely setose, with later- 


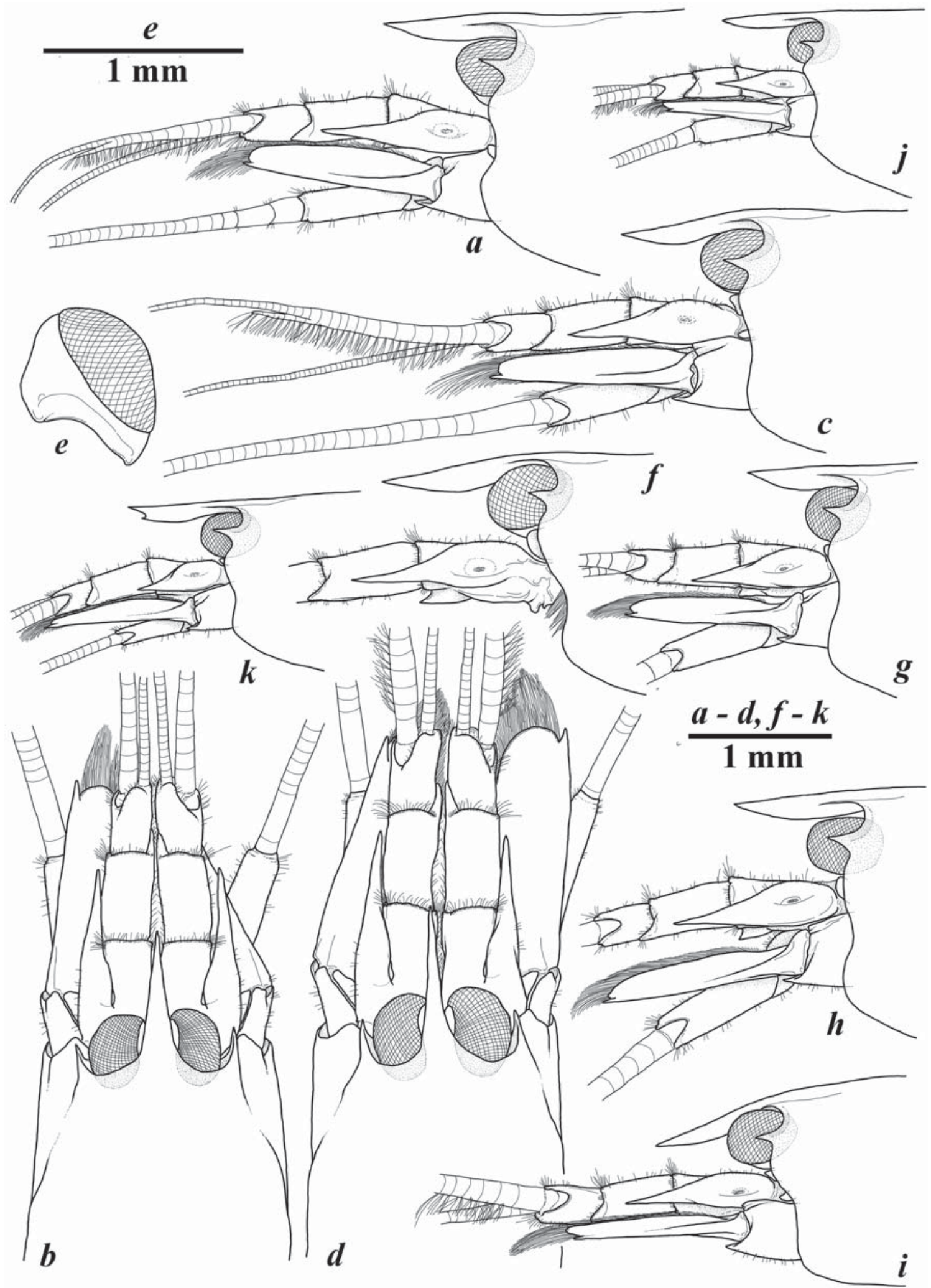

Fig. 3. Potamalpheops kisi sp.n., holotype + (ZMMU Ma-6118) $(a, b)$, allotype $\sigma^{7}$ (ZMMU Ma-6119) (c, d), paratypes + (LEMMI) (g, $h$ ), paratypes $O^{\top} O^{\top}$ (LEMMI) $(f, i)$, juvenile specimens, paratypes $(j, k): a, c, f-k$ - front of carapace, lateral view; $b, d-$ front of carapace, dorsal view; $e-$ eye.

Pис. 3. Potamalpheops kisi sp.n., голотип $q$ (ZMMU Ma-6118) $(a, b)$, аллотип $0^{\top}$ (ZMMU Ma-6119) (c, $d$ ), паратипы фо (LEMMI) $(g, h)$, паратипы $O^{7} \sigma^{7}$ (LEMMI) $(f, i)$, ювенильные особи, паратипы $(j, k): a, c, f-k$ - передняя часть карапакса, вид сбоку; $b, d-$ передняя часть карапакса, вид сверху; $e$ - глаз. 


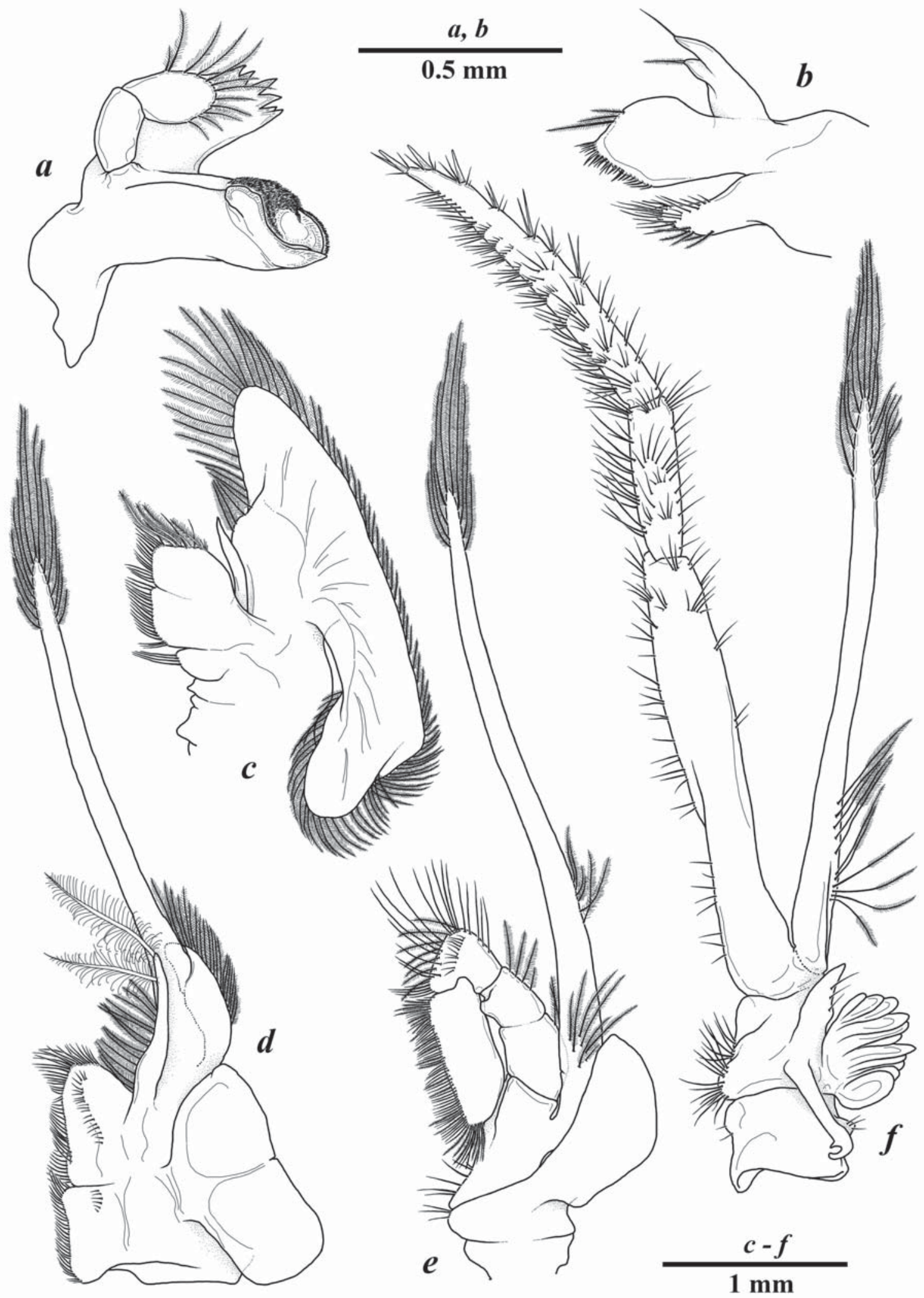

Fig. 4. Potamalpheops kisi sp.n., paratype + (LEMMI): $a$ - mandible; $b$ - maxillula; $c$ - maxilla; $d$ - maxilliped I; $e$ - maxilliped II; $f$ - maxilliped III.

Рис. 4. Potamalpheops kisi sp.n., паратип + (LEMMI): $a$ — мандибула; $b$ — максиллула; $c$ — максилла; $d$ — максиллипеда I; $e$ максиллипеда II; $f$ - максиллипеда III. 


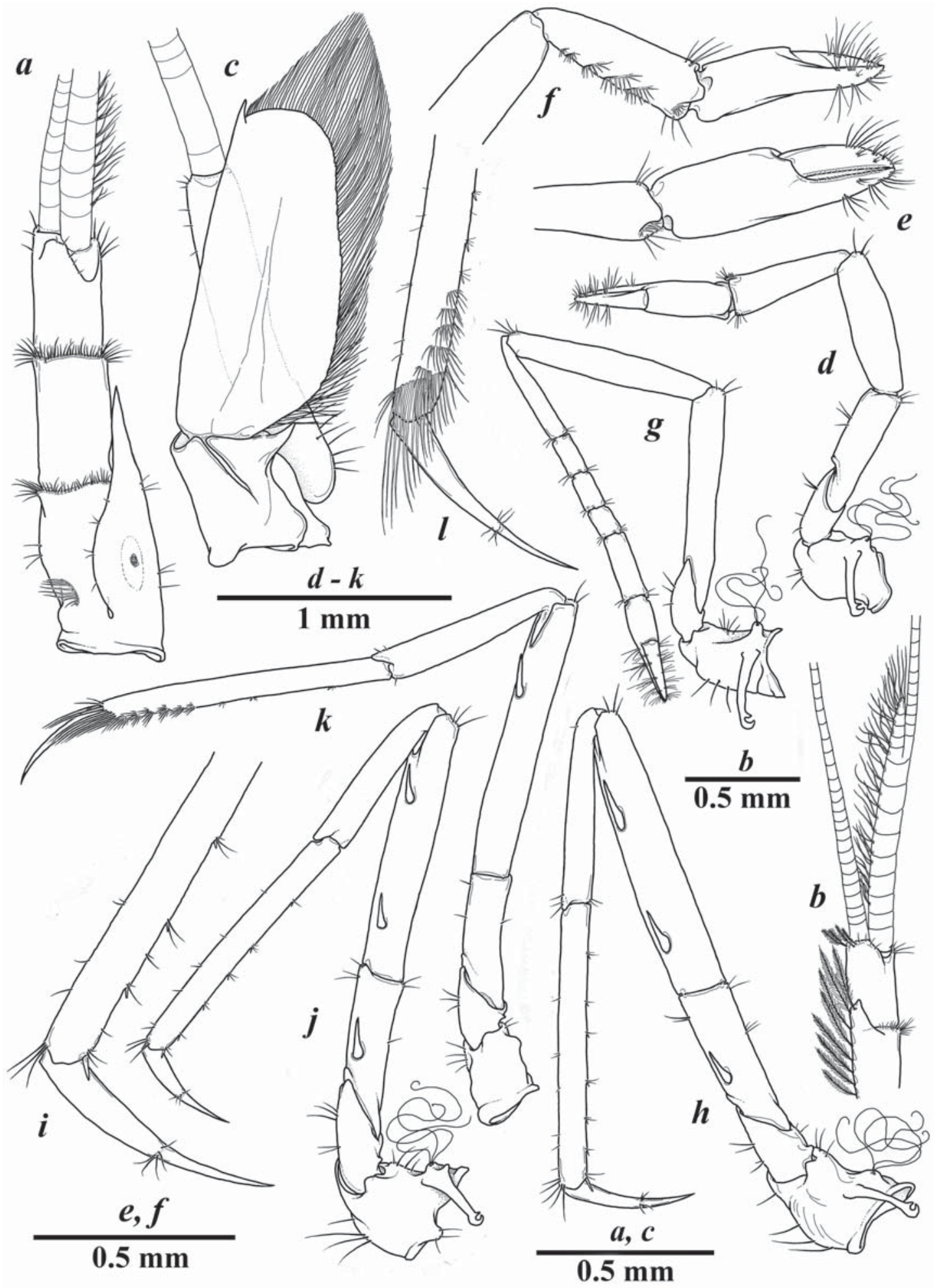

Fig. 5. Potamalpheops kisi sp.n., paratype $q$ (LEMMI): $a$ - right antennular peduncle; $b$ - right flagella and article 3 of antennular peduncle; $c$ - left antenna; $d$ - left pereiopod I; $e, f$ - carpus and chela of left pereiopod I, mesial and extensor views; $g$ - left pereiopod II, lateral view; $h$ - pereiopod III; $i$ - dactylus of left pereiopod III, lateral view; $j$ - left pereiopod IV, lateral view; $k$ - left pereiopod V, lateral view; $l$ - distal part of propodus and dactylus of pereiopod $\mathrm{V}$, lateral view.

Pис. 5. Potamalpheops kisi sp.n., паратип 9 (LEMMI): $a-$ стебелек правой антеннулы; $b-$ правый жгутик и членик 3 стебелька антеннул; $c$ - левая антенна; $d$ - левая переопода I; $e, f$ - карпус и клешня переоподы I, мезиальный вид; $g$ - левая переопода I, вид сбоку; $h$ - переопода III; $i$ - дактилус левой переоподы III, вид сбоку; $j$ - левая переопода IV, вид сбоку; $k-$ левая переопода $\mathrm{V}$, вид сбоку; $l$ - дистальная часть проподуса и дактилуса переоподы $\mathrm{V}$, вид сбоку. 
al plate acutely pointed distolaterally, with small epipod.

Pereiopod I (Fig. 5d) small, similar in size and equal in shape both in males and females; coxa unarmed, with epipod and setobranch consisting of 3 setae; basis short, about as long as wide, unarmed; ischium about twice longer than basis, about 3.5 times as long as wide, unarmed; merus about 3 times as long as central width, slightly swollen centrally, unarmed; carpus (Fig. 5f) slightly shorter or subequal to merus, about 1.3 times longer than palm, about 3.5 times as long as wide, widening distally, with grooming apparatus consisting of 4 transverse rows of serrulate spines medially; chela (Fig. 5e, $f$ ) with subcylindical palm, about 2.5 times as long as wide, smooth; fingers stout, about 0.7 of palm length, cutting edges entire, situated slightly laterally, with several tiny distal teeth (Fig. 5e).

Pereiopod II (Fig. 5g) moderately slender, extending to distal margin of antennular peduncle; coxa with epipod and setobranch consisting of 3 setae; basis about as long as wide, smooth, unarmed; ischium slightly broadened distally, about 6 times as long as distal width, unarmed; merus subcylindrical, subequal in length to ischium, about 7 times as long as wide, unarmed; carpus 5-segmented, about 2 times longer than merus and 4 times longer than palm, segment ratio $3: 1: 1: 1: 2$; chela small, palm subcylindrical, moderately compressed, about 1.4 times as long as wide, fingers about 1.1 times longer than palm, about 3.5 times as long as wide, cutting edges entire, tips simple.

Ambulatory pereiopods moderately robust, pereiopod V reaching to about end of antennular peduncle. Pereiopod III (Fig. 5h) moderately robust; coxa with epipod and setobranch, and also with several simple setae; basis about 1.5 times as long as wide, mostly smooth, unarmed; ischium about 2.5 times as long as wide, with movable spine ventrolaterally; merus about 6.5 times as long a wide, subcylindrical, with 2 widely spaced robust ventrolateral movable spines, located at 0.25 and 0.75 of its length; carpus about 5.5 times as long as wide, about half of length of both merus and propodus; propodus straight, about 9 times as long as wide, subcylindrical, with a series of movable spinules on flexor margin; dactyl (Fig. 5i) slender, simple, about 0.4 length of propodus, unguis feebly demarcated from corpus, slender, 4 times longer than proximal width, curved ventrally, corpus straight, about 4 times longer than proximal width, with 2 groups of minute, simple setae subdistally. Pereiopod IV (Fig. 5j) almost similar to pereiopod III; coxa with epipod and setobranch; ischium with movable spine ventrolaterally; merus with 2 movable spines; propodus slightly shorter than propodus of pereiopod III. Pereiopod V (Fig. 5k) slenderer than pereiopods III and IV; coxa with setobranch, without epipod; basis about as long as wide, unarmed; ischium about 2.5 times as long as wide, unarmed; merus about 7 times as long as wide, with 1 movable spine at distal 0.3 of its length; carpus about 6 times as long as distal width; propodus about 10 times as long as wide, with 7-8 transverse rows of serrulate setae on flexor lateral surface (seate increasing in number and length distally), and with small distoventral spinule medially; dactyl (Fig. 5l) slender, about 0.3 of the length of propodus, unguis feebly demarcated from corpus, slender, about 4 times longer than proximal width, curved ventrally, corpus straight, 4 times longer than proximal width, with 2 groups of minute, simple setae subdistally.

Pleopods (Fig. 6f, $g$ ) normal, without lamellar medial expansions along lateral margins. Pleopod I in males (Fig. 6f) with protopodite about 2 times longer than maximal width, tapering proximally; endopod about 4 times as long as proximal width, mesial margin with short plumose setae. Pleopod II in males (Fig. 6e) with protopodite about 2.5 times as long as wide, widened distally; endopod (Fig. 6h) with appendices interna and masculine located at midlength, posterior medial and distal margins with numerous long plumose setae; appendix masculina slender, subcylindrical, about 8 times as long as wide, reaching to about 0.9 of endopod length, with 7 slender simple spiniform setae distally (Fig. 6i); appendix interna short, about half length of appendix masculina, distally with 5-6 cincinnuli (Fig. 6j).

Uropod (Fig. $6 b, d$ ) with protopodite bearing large acute, distodorsal lobe, endopod exceeding posterior telson spines (Fig. 6b); exopod about 3 times as long as broad, with straight lateral margin, bearing submarginal setal fringe, terminating in small acute distal tooth; diaeresis (Fig. 6e) very well developed, reaching lateral $3 / 4$ of dorsal flange, flange with small triangular teeth; endopod about 0.9 of exopod length, about 3 times as long as wide, with a longitudinal row of small spines along its median part.

COLOURATION IN LIFE. Body generally semi-translucent, with reddish or violet chromatophores, forming broad transverse bands on carapace and pleon, telson and uropods edged with similarly colored chromatophores; antennal segments and maxilliped III densely covered with red or brown chromatophores; both chelipeds and ambulatory pereopods translucent (Fig. 6).

SIZE. Largest ovigerous female has tl. $14 \mathrm{~mm}$, cl. 3.7 $\mathrm{mm}$, egg size $0.5 \times 0.3 \mathrm{~mm}$; largest male has tl. $12 \mathrm{~mm}$, cl. 3.0 $\mathrm{mm}$.

ETYMOLOGY. The new species is named after the Vietnam-Russian CRS "Can Gio", located at the Can Gio Mangrove Biosphere Reserve, South Vietnam, near which the species was discovered. Climatic Research Station is $K I S$ in the Russian transcription.

HABITAT AND ECOLOGY. The specimens of the new species were pumped using hand yabbi-pump from both dry and water-filled parts of numerous invertebrate burrows in mangrove swamps, which are exposed for a longer period during low tide due, and neighboring coastal slope of tidal creeks during the day and night sampling. Burrows were made in deep dark gray or black marsh mangrove soil with low aeration and a specific smell hydrogen sulfide, resulted from the activity of anaerobic sulfur-reducing bacteria. Herewith, no individuals of the new species were collected using a hand net during the extensive sampling in the same habitats, under the dense roots of mangrove trees Rhizophora apiculata or puddles as well as in tidal creeks and the upper swamp mud during the high tide. According to our observations, the species most likely obligatory lives in the continuous system of numerous burrows, but is not specifically associated with any host, since we never pumped individuals of the new species together with another species of burrowing invertebrates. At the same time, numerous individuals of two species of pistol shrimps from Alpheus euphrosyne de Man, 1897 and Alpheus lobidens De Haan, 1850 complexes (Crustacea: Decapoda: Alpheidae) (often in ${ }^{\circ} \mathrm{O}^{7}$ pairs), stomatopods Clorida rotundicauda (Miers, 1880) (Crustacea: Decapoda: Squillidae), crabs of the genus Metaplax H. Milne Edwards, 1852 (Crustacea: Decapoda: Varunidae), different gobies and, possibly, new infaunal species of the genus Salmoneus Holthuis, 1955 were pumped out from the same habitats during the sampling. All of them are specific representing a stable community, characteristic for the mangrove swamps, wetland pools and tidal creeks in the 


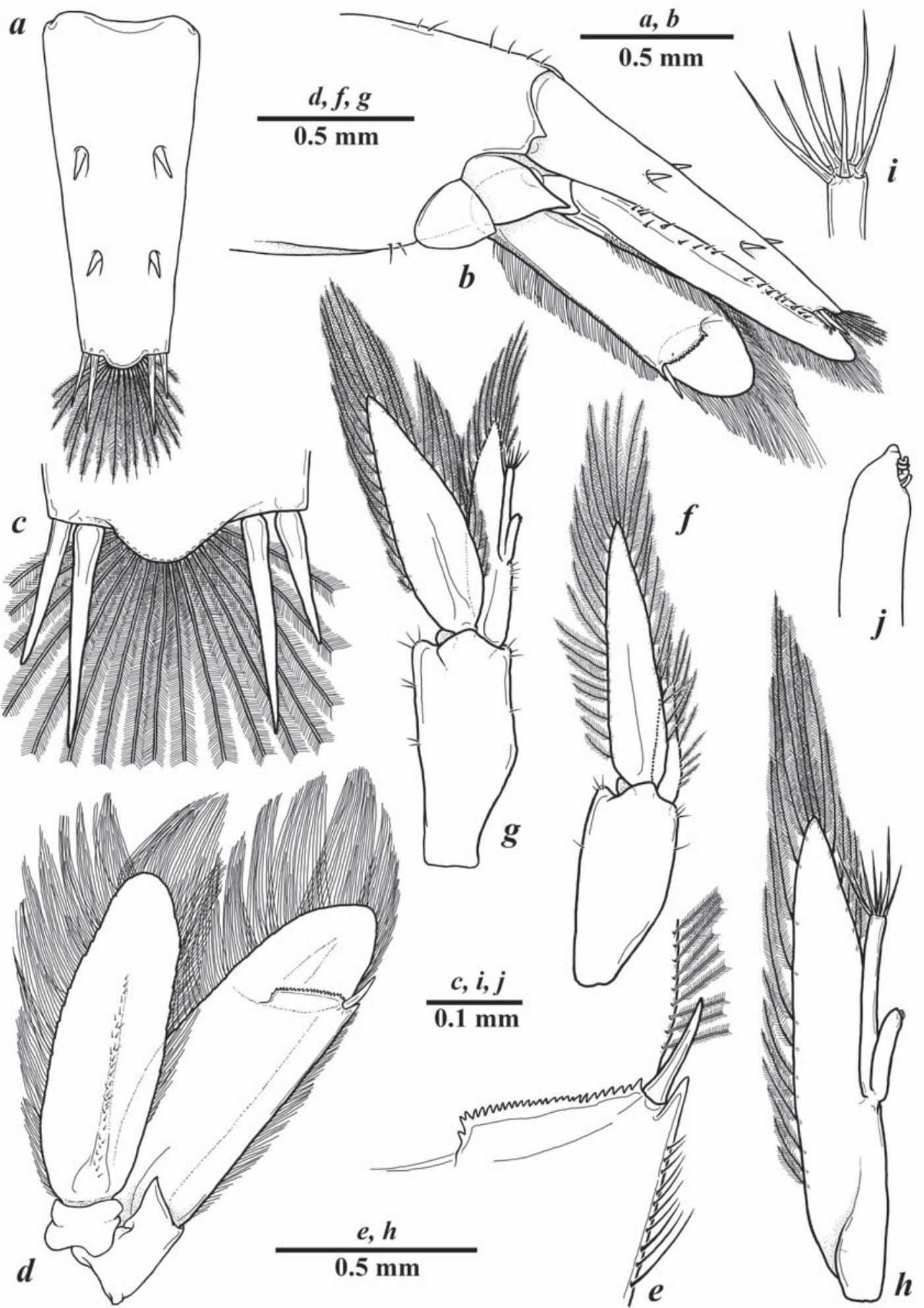

Fig. 6. Potamalpheops kisi sp.n., paratype + (LEMMI) $(a-e)$, paratype $\sigma^{7}$ (LEMMI) $(e-i): a-$ telson, dorsal view; $b-$ telson and uropods, lateral view; $c$ - distal margin of telson, dorsal view; $d$ - left uropods, dorsal view; $e$ - distolateral part of uropodal exopod with diaresis; $f$ - right pleopods I; $g$ - right pleopod II; $h$ - exopod of pleopod II; $i$ - distal part of appendix masculina; $j$ - distal part of appendix interna.

Рис. 6. Potamalpheops kisi sp.n., паратип + (LEMMI) ( $a-e)$, паратип О (LEMMI) $(e-i): a-$ тельсон, вид сверху; $b-$ тельсон и уроподы, вид сбоку; $c$ - дистальный край тельсона, вид сверху; $d$ - левый уропод, вид сверху; $e$ - дистолатеральная часть экзопода уропод с диарезисом; $f$ - правый плеопод I; $g$ - правый плеопод II; $h$ - экзопод плеоподы II; $i$ - дистальная часть appendix masculina; $j$ - дистальная часть appendix interna. 

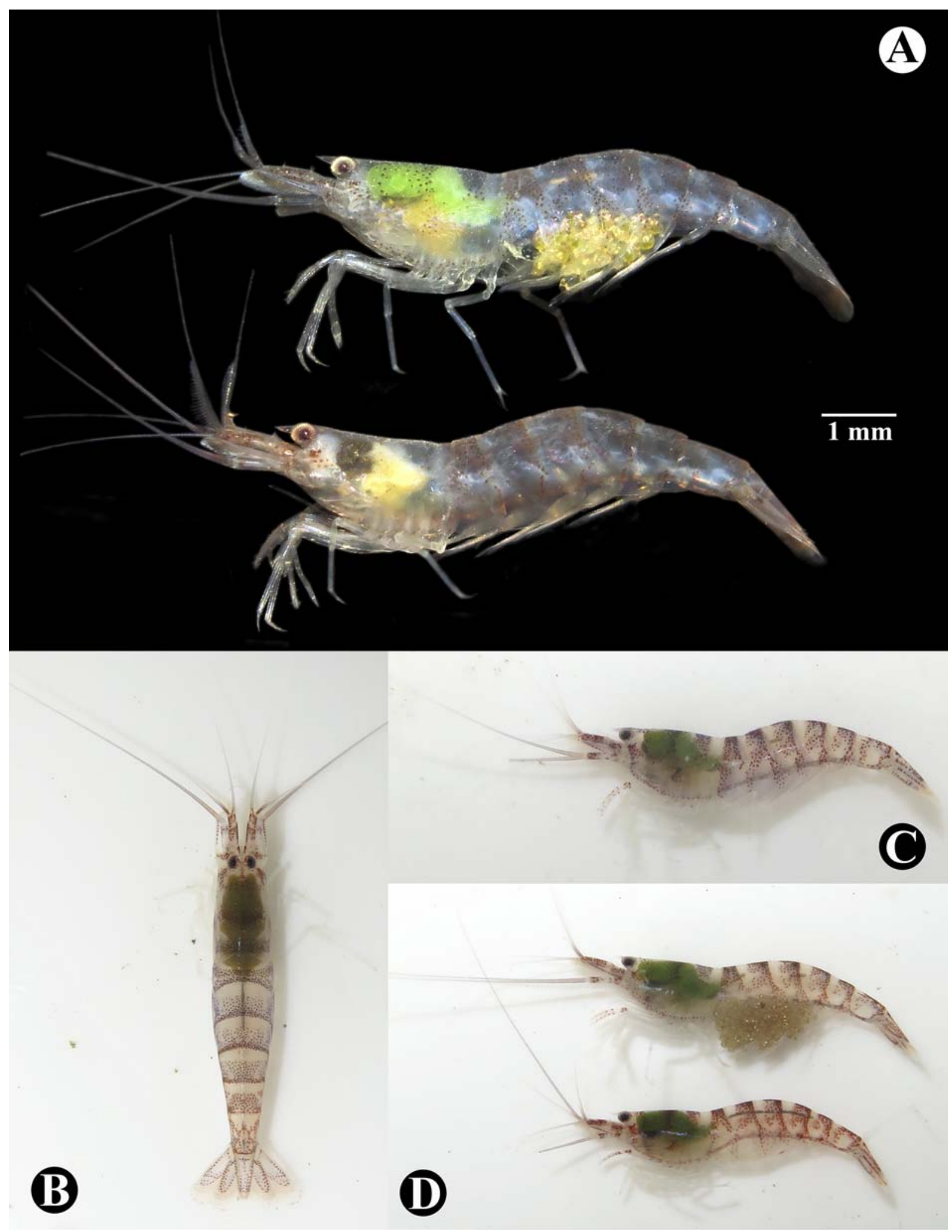

Fig. 7. Living coloration of Potamalpheops kisi sp.n.: A $-\uparrow$ and $\sigma^{7}$, paratypes (LEMMI), lateral view; B — paratype + (LEMMI), dorsal view; C, D - paratype +OT $^{7}$ (LEMMI), lateral view.

Рис. 7. Прижизненная окраска Potamalpheops kisi sp.n.: А — + и О’, паратипы (LEMMI), вид сбоку; б — паратип + (LEMMI), вид сверху; В, Г — паратипы †от (LEMMI), вид сбоку. 
Can Gio Mangrove Biosphere Reserve and were not found on the intertidal mudflats or in mangrove estuary.

Observations in situ at night time in dry part of vertical and semi-horizontal large-sized burrows of probably unidentified crabs (Parasesarma sp. (Crustacea: Decapoda: Sesarmidae) or Metaplax sp.) revealed that Potamalpheops kisi sp.n. can freely move inside burrows located above the water level, even very quickly avoiding capture. Possible this is adaptive behavior allowing surviving in anoxic conditions of mangrove swamps. For example, the specimens of Potamalpheops hanleyi Bruce, 1991 were also found in semi-terrestrial habitats in a high humidity niche beneath wooden bark of fallen rotten timber during low tide, well above mean tide level in an area of mangrove swamp [Bruce, 1991]. Such behavior is similar to other semi-terrestrial mangrove shrimp Merguia oligodon (De Man, 1888) (Crustacea: Decapoda: Merguidae) living inside burrows of Neosarmatium smithi $\mathrm{H}$. Milne Edwards, 1853 (Crustacea: Decapoda: Sesarmidae) in Kenyan mangroves [Gillikin et al., 2001].

Actually, mangrove intertidal forests are inhabited by a diverse and specific macro-fauna, characterized by marine taxa, which developed evolutionary trends to semi-terrestrial and terrestrial life-styles as well as some terrestrial species are re-adapted to marine life [Cannicci et al., 2012; Giomi et al., 2012; Ngo-Massou et al., 2012; Ravichandran, Wilson, 2012; Vannini, Fratini 2012].

GENBANK ACCESSION NUMBERS. MW803169, MW803170, MW808997.

DISTRIBUTION. Only known from mangrove swamps of the Can Gio Mangrove Biosphere Reserve, South Vietnam.

TAXONOMIC REMARKS. Potamalpheops kisi sp.n. belongs to the "Potamalpheops monodi (Sollaud, 1932)" species group, characterized by well-developed rostrum, the possession of 2 pairs of posterior telson spines and feebly developed chela of the pereiopod I not carried in a flexed position [Bruce, 1991; Bruce, Illife, 1992; Anker, 2003], and is closely related to $P$. pininsulae Bruce et Illife, 1992, $P$. tigger Yeo et P.K.L. Ng, 1997 and P. johnsoni Anker, 2003.

From $P$. pininsulae, the new species can be separated by 1) ventrally unarmed rostrum in mature specimens (Fig. 3) (although small distoventral tooth can be occasionally found in juveniles (Fig. $3 k$ )) (vs. rostrum with distinct distoventral tooth in mature specimens in $P$. pininsulae [Bruce, Illife, 1992: figs 2, 4]); 2) longer antennular stylocerite, overreaching midlength of second segment of antennular peduncle (Fig. 3) (vs. slightly overreaching distal margin of basal segment of antennular peduncle in $P$. pininsulae [Bruce, Illife, 1992: figs 2, 3 6]); 3) unarmed distodorsal margin of basal segment of antennular peduncle (Fig. $5 a$ ) (vs. distinctly serrated in $P$. pininsulae [Bruce, Illife, 1992: fig. 6]); 4) presence of ingle seta on each distal lobe of palp of maxillula (Fig. 4b) (vs. more than 3 setae on each lobe in $P$. pininsulae [Bruce, Illife, 1992: fig. 37]); 5) stouter carpus of pereiopod I, which is about 3.5 times as long as wide (Fig. $5 d, f$ ) (vs. about 4.5 times as long in $P$. pininsulae [Bruce, Illife, 1992: fig. 20]); 6) relatively slender and longer unguis of dactyli of ambulatory pereiopods (Fig. $5 i, l$ ) (vs. stout unguis in $P$. pininsulae [Bruce, Illife, 1992: fig. 47]); and 7) appendix masculina only with distal setae (Fig. 6h, $i$ ) (vs. with numerous setae extending along lateral margin of appendix masculina in $P$. pininsulae [Bruce, Illife, 1992: fig. 42]).

From $P$. tigger, the new species can be separated by 1) proportionally shorter rostrum, reaching only distal mar- gin of basal segment of antennular segment (Fig. 3) (vs. distinctly overreaching distal margin of basal segment of antennular peduncle in $P$. tigger [Yeo, Ng, 1997: fig. 5a, b; Anker, 2003: fig. $4 a, k]$ ); 2) proportionally longer carpus of pereiopod I, which is as long as chela (Fig. $5 d, f$ ) (vs. about 0.7 times as long as chela in P. tigger [Yeo, Ng, 1997: fig. 6b; Anker, 2003: fig. 4l]); 3) distinctly longer carpal segments of pereiopod II, which are longer than ischium for about twice of it length (Fig. 5g) (vs. for 1.4-1.5 of its length in P. tigger [Yeo, Ng, 1997: fig. 6c; Anker, 2003: fig. $4 \mathrm{~m}]$ ); dorsal spines on telson locate at 0.4 and 0.65 of its length (Fig. $6 a$ ) (vs. at 0.5 and 0.8 in P. tigger [Yeo, $\mathrm{Ng}$, 1997: fig. 5d]).

From $P$. johnsoni, the new species can be separated by 1) slender rostrum without distoventral tooth in mature specimens (Fig. 3), exceptionally with small distoventral tooth in one of juvenile specimen (Fig. 4k) (vs. rostrum occasionally with somewhat expanded ventral blade and distinct ventral tooth in P. johnsoni [Anker, 2003: fig. 5]); 2) slender carpus and propodus of pereiopod I (Fig. 5d-f) (vs. Anker, 2003: fig. $6 a-d)$; 3) larger spines on ischium and propodus of pereiopod III and IV (Fig. 5h,j, $k$ ) (vs. Anker, 2003: fig. 6f, $h$ ); and 4) position of dorsal spines is closer to the center of telson (Fig. 6a) (vs. submarginal position in $P$. johnsoni [Anker, 2003: fig. 6j, $l]$ ).

Out of the "P. monodi" species group, from other IndoWest Pacific species of the genus Potamalpheops, namely P. hanleyi Bruce, 1991, P. darwiniensis Bruce, 1993, P. amnicus Yeo et P.K.L. Ng, 1997, P. miyai Yeo et P.K.L. $\mathrm{Ng}, 1997, P$. palawensis Cai et Anker, 2004 and $P$. galle Anker, 2005, the new species can be separated by a longer rostrum reaching or slightly exceeding distal margin of basal segment of antennular peduncle and longer stylocerite overreaching distal margin of the basal segment of antennular peduncle. These features are very stable and useful for the species identification within the genus.

\section{Discussion}

Presently, the genus Potamalpheops consists of 15 described species [De Grave, Fransen, 2011; updated by Soledade et al., 2014] and this new species increases the genus diversity up to 16 species. Possibly the genus Potamalpheops originated in Upper Cretaceous (80-90 Mya) and, possibly, previously possessed a Tethyan distribution because of the modern disjunctive distributional pattern of the genus [Bruce, 1991]. At present time, representatives of the genus inhabit mainly brackish and mangrove biotopes in transitional zones between marine, oligohaline and freshwaters in tropical zones of South America, West Africa, South and Southeastern Asia, with two obligatory cave-dwelling (P. stygicola and P. nazgul) and even two obligatory freshwater species ( $P$. amnicus and $P$. palawaensis) [Cai, Anker, 2004; Anker, 2005; Christodoulou et al., 2016]. This genus seems to have a very high tolerance to change of salinity and other conditions, since dark gray or black marsh mangrove soils below the surface is characterized by low aeration and the presence of hydrogen sulfide, resulted of the activity of anaerobic sulfur-reducing bacteria (e.g. Desuifovibrio sp.), which thrive in anoxic conditions [Ng, Sivasothi, 2002; Hossain, Nuruddin, 2016]. This creates very difficult and 
even extreme conditions, for the habitat of various burrowing species, most of which are specific and adapted for mangrove swamps. Most of deep mangrove species are highly specialized to such conditions.

The present new species represent the first record of the genus from mangrove swamps and creeks of Vietnam, although the occurrence is not surprising, since the genus is quite widespread in mangrove communities of southeastern Asia [Anker, 2005], and almost all species are isolated either ecologically or geographically. Molecular-genetic studies have revealed strict geographical patterns in species distribution in mangrove-dwelling slugs of the genera Wallaconchis Goulding et Dayrat, 2018 [Goulding et al., 2018] and Onchidium Buchannan, 1800 (Gastropoda, Euthyneura, Pulmonata, Onchidiidae) [Dayrat et al., 2019], which are usually syntopic with Potamalpheops. Therefore, narrow distribution areas and high level of endemism are also possibly characteristic of the genus Potamalpheops, but it requires serious molecular genetic studies. Unfortunately, molecular genetic data on the species of the genus Potamalpheops is currently only available for this new species. The search for suitable individuals for molecular genetic research among closely related species $(P$. pininsulae, $P$. tigger and $P$. johnso$n i)$ also failed, since most of specimens were collected and deposited in the museum collections more than 15 years ago. However, the data obtained for the new species described herewith can be used in the future for taxonomic and phylogenetic studies.

Acknowledgements. This study was supported by the Russian Foundation of Basic Researches (RFBR) with grant grants Nos 18-04-01093 A and 20-04-00803 A. Author is deeply grateful to the co-directors of the Southern Department of the Russian-Vietnam Tropical Centre (Ho Chi Minh City, Vietnam) and Sergey Sinelnikov (A.N. Severtsov Institute of Ecology and Evolution of RAS, Moscow) for the help during the field sampling; to Prof. Rudolf N. Burukovsky (Kaliningrad State Technical University, Kaliningrad, Russia) for valuable comments to the manuscript.

\section{References}

Anker A. 2003. Alpheid shrimps from the mangroves and mudûats of Singapore. Part I. Genera Salmoneus, Athanas and Potamalpheops, with the description of two new species (Crustacea: Decapoda: Caridea) // The Rafûes Bulletin of Zoology. Vol.51. P.283-314.

Anker A. 2005. Presence of the alpheid shrimp genus Potamalpheops Powell, 1979 (Crustacea: Decapoda: Caridea) in South Asia, with description of a new species from Sri Lanka // The Rafûes Bulletin of Zoology. Suppl.12. P.31-37.

Ashelby C.W., De Grave S., Van Xuan N. 2018. A new species of Palaemon from Can Gio District, Vietnam, previously confused with Palaemon sewelli (Kemp, 1925) // Crustacean Research. Vol.47. P.17-27. https://doi.org/10.18353/crustacea. $47.0 \quad 17$

Avise J.C. . 1993. Perspective: The evolutionary biology of aging, sexual reproduction, and DNA repair // Evolution. Vol.47. No.5. P.1293-1301. https://doi.org/10.1111/j.1558-5646.1993. tb02155.x

Bruce A.J. 1991. The "African" shrimp genus Potamalpheops in Australia, with the description of $P$. hanleyi, new species (De- capoda: Alpheidae) // Journal of Crustacean Biology. Vol.11. No.4. P.629-638. https://doi.org/10.2307/1548531

Bruce A.J., Iliffe T.M. 1992. Potamalpheops pininsulae sp. n., a new stygiophilic shrimp from New Caledonia (Crustacea: Decapoda: Alpheidae) // Stygologia. Vol.7. No.4. P.231-242.

Cai Y., Anker A. 2004. On a collection of freshwater shrimps (Crustacea Decapoda Caridea) from the Philippines, with descriptions of five new species // Tropical Zoology. Vol.17. No.2. P.233-266. https://doi.org/10.1080/03946975.2004. 10531207

Cannicci S., Bartolini F., Penha-Lopes G., Fratini S., Fusi M., Dahdouh-Guebas F., 2012. Functions of macrobenthos in mangrove forests: $>20$ years of research lessons // VLIZ Special Publication. Vol.7. P.184.

Chertoprud E.S., Spiridonov V.A., Marin I.N., Mokievsky V.O. 2012. Brachyuran crabs (Crustacea Decapoda Brachyura) of the mangrove intertidal zone of southern Vietnam // Britayev T.A., Pavlov D.S. (eds.). Benthic fauna of the Bay of Nhatrang, Southern Vietnam. Vol.2. Moscow: KMK Scientific Press. P. 258-295.

Christodoulou M., Anastasiadou Ch., Jugovic J., Tzomos Th. 2016. Freshwater shrimps (Atyidae, Palaemonidae, Typhlocarididae) in the broader Mediterranean Region: Distribution, life strategies, threats, conservation challenges and taxonomic issues // Kawai T., Cumberlidge N. (eds.). A Global Overview of the Conservation of Freshwater Decapod Crustaceans. New York: Springer. P.199-236. https://doi.org/10. 1016/j.jcz.2019.08.008

Dayrat B., Goulding T.C., Khalil M., Apte D., Tan S.H. 2019. A new species and new records of Onchidium slugs (Gastropoda, Euthyneura, Pulmonata, Onchidiidae) in South-East Asia // ZooKeys. Vol.892. P.27-57. https://doi.org/10.3897/zookeys. 892.39524

De Grave S., Fransen C.H.J.M. 2011. Carideorum catalogus: the recent species of the dendrobranchiate, stenopodidean, procarididean and caridean shrimps (Crustacea, Decapoda) // Zoologische Mededelingen. Vol.85. No.9. P.195-588.

Diele K., Ngoc D.T., Geist S.J., Meyer F.W., Pham Q.H., SaintPaul U., Tran T., Berger U. 2013. Impact of typhoon disturbance on the diversity of key ecosystem engineers in a monoculture mangrove forest plantation, Can Gio Biosphere Reserve, Vietnam // Global and Planetary Change. Vol.110. P.236-248. https://doi.org/10.1016/j.gloplacha.2012.09.003

FAO. 1993. Mangrove for production and protection. A changing Resource System: Case Study in Can Gio District, South Vietnam. Field Document No.43. Food and Agriculture Organization of the United Nations, Bangkok.

FAO. 2007. The world's mangroves 1980-2005. FAO Forestry Paper 153. Food and Agriculture Organization of the United Nations, Rome

Folmer O., Black M., Hoeh W., Lutz R., Vrijenhoek R. 1994. DNA primers for amplification of mitochondrial cytochrome c oxidase subunit I from diverse metazoan invertebrates // Molecular Marine Biology and Biotechnology. Vol.3. P.294-299.

Gillikin D.P., De Grave S., Tack J.F. 2001. The Occurrence of the Semi-Terrestrial Shrimp Merguia oligodon (De Man, 1888) in Neosarmatium smithi H. Milne Edwards, 1853 Burrows in Kenyan Mangroves // Crustaceana. Vol.74. No.5. P.505-507. https://doi.org/10.1163/156854001750243081

Giomi F., Simoni R., Mostert B., Fusi M., Porri F., McQuaid C., Pörtner H.-O., Cannicci S. 2012. Biology of crab embryos in mangrove forests: from evolutionary trends to climate change perspectives // VLIZ Special Publication. Vol.57. P.72.

Goldstein A., Turner W.R., Spawn S.A. et al. 2020. Protecting irrecoverable carbon in Earth's ecosystems // Nature Climate Change. Vol.10. P.287-295. https://doi.org/10.1038/s41558020-0738

Goulding T.C., Khalil M., Tan S.H., Dayrat B. 2018. Integrative taxonomy of a new and highly-diverse genus of onchidiid slugs from the Coral Triangle (Gastropoda, Pulmonata, Onchidiidae) // ZooKeys. Vol.763. P.1-111. https://doi.org/10.3897/ zookeys.763.21252 
Hossain M.D., Nuruddin A.A. 2016. Soil and Mangrove: A Review // Journal of Environmental Science and Technology. Vol.9. No.2. P.198-207. https://doi.org/10.3923/jest.2016.198.207

Kessing B., Croom H., Martin A., McIntosh C., Mc Millan W.O. Palumbi S. 1989. The simple fool's guide to PCR, version 1.0. Department of Zoology, University of Hawaii, Honolulu.

Knowlton N., Weigt L.A., Solórzano L.A., Mills D.K., Bermingham E. 1993. Divergence in proteins, mitochondrial DNA, and reproductive compatibility across the Isthmus of Panama // Science. Vol.260. P.1629-1632.

Moberg F., Rönnbäck P. 2003. Ecosystem services of the tropical seascape: interactions, substitutions and restoration // Ocean \& Coastal Management. Vol.46. P.27-46. https://doi.org/10.1016/ S0964-5691(02)00119-9

Ng P.K.L., Sivasothi N. 2002. A guide to the mangroves of Singapore 1: The ecosystem and plant diversity. Singapore: Singapore Science Centre. 160 pp.

Ngo-Massou V.M., Nfotabong Atheull A., Essomè-Koum G.L. Din N., 2012. Diversity of crabs and molluscs macrofauna in mangrove of Wouri estuary (Douala - Cameroon) // VLIZ Special Publication. Vol.57. P.130.

Ravichandran S., Wilson F.S. 2012. Variations in the crab diversity of the mangrove environment from Tamil Nadu, Southeast coast of India // VLIZ Special Publication. Vol.57. P.152

Shih H.-T., Hsu J.-W., Wong K.J.H., Ng N.K. 2019. Review of the mudflat varunid crab genus Metaplax (Crustacea, Brachyura, Varunidae) from East Asia and northern Vietnam // ZooKeys Vol.877 P.1-29. http://dx.doi.org/10.3897/zookeys.877.38300

Soledade G.O., Santos P.S., Almeida A.O. 2014. Potamalpheops tyrymembe sp. n.: the first southwestern Atlantic species of the shrimp genus Potamalpheops Powell, 1979 (Caridea: Alpheidae) // Zootaxa. Vol.3760. No.4. P.579-586. https://doi.org/ 10.11646/zootaxa.3760.4.7
Tran T., Barzen J., Le Cong K., Moore D. 2004. War-time herbicides in the Mekong delta and their implications on post-war wetland conservation // Furukawa H., Nishibuchi M., Kono Y,. Kaida Y. (eds.). Ecological Destruction, Health and Development Advancing Asian Paradigms. Kyoto University Press and Trans Pacific Press. P.199-211.

Valiela I., Bowen J.L., York J.K. 2001. Mangrove forests: one of the World's threatened major tropical environments // BioScience. Vol.51. P.807-815. https://doi.org/10.1641/00063568(2001)051[0807:MFOOTW]2.0.CO;2

Van Xuan N. 1992. Review of Palaemoninae (Crustacea: Decapoda: Caridea) from Vietnam, Macrobrachium excepted // Zoologische Mededelingen. Vol.66. No.2. P.19-47.

Van Xuan N. 2001. A new alpheid shrimp (Crustacea: Decapoda: Alpheidae) from South Vietnam // Zoologische Mededelingen. Vol.75. No.1-15. P.217-228.

Vannini M., Fratini S. 2012. The tree-climbing behavior of Cerithidea decollata (Mollusca: Potamididae): how does this snail decide when to climb and where to stop? // VLIZ Special Publication. Vol.7. P.184.

Walters B.B., Rönnbäck P., Kovacs J.M., Crona B., Hussain S.A., Badola R., Primavera J.H., Barbier E., Dahdouh-Guebas F. 2008. Ethnobiology, socio-economics and management of mangrove forests: a review // Aquatic Botany. Vol.89. P.220-236, http://doi.org/10.1016/j.aquabot.2008.02.009

Yeo D.C.J., Ng P.K.L. 1997. The alpheid shrimp genus Potamalpheops Powell, 1979, (Crustacea: Decapoda: Caridea: Alpheidae) from Southeast Asia, with descriptions of three new species // Journal of Natural History Vol.31. No.2. P.163-190. https://doi.org/10.1080/00222939700770111

Responsible editor K.G. Mikhailov 